\title{
Research on the Problems and Countermeasures in the Reform of Public Art Education in Colleges
}

\author{
Zhiyuan Yan \\ Henan University of Animal Husbandry and Economy, Zhengzhou, Henan, 450046, China
}

Keywords: colleges; public art education; reform ideas; countermeasures

\begin{abstract}
Public art education is an important part of public education in ordinary colleges and universities. It plays an irreplaceable role in improving the overall artistic quality of college students. At present, although public art education has played a greater role in advancing the healthy growth of college students and the development of higher education, and has achieved certain results, it is still a weak link in college education. To effectively change the current situation of public art education in colleges and universities, it is necessary to increase the reform of public art education and integrate public art education work into the entire higher education work.
\end{abstract}

\section{Introduction}

The content of public art education is very rich, covering the art form, ontology form, creation form and concept, creation techniques and methods, and aesthetic consciousness of public art. In the process of public art education in colleges, students should master the basic knowledge theory and methods of appreciation in public art, so that students can learn to appreciate and judge various art categories. This will help them gradually become a person with artistic accomplishment and then inspire their innovation.

\section{Problems in Public Art Education in Colleges}

\subsection{The Ambiguous Orientation of the Subject.}

Because public art education is a new discipline, most colleges and universities do not regard it as a complete discipline to build or integrate it with the entire curriculum system of the school. Its positioning in the discipline construction is more vague and casual. The main manifestations are unclear teaching objectives, the lack of integrated planning for subject construction, and the lack of due attention from school authorities. It is particularly necessary to point out that under the influence of utilitarianism, some colleges and universities violate the teaching goal of popularizing public art education and improving college students' artistic accomplishment to raise students' skill training. They are keen on competitions, and regard the ranking and awards as the ultimate goal of public art education. They put the disciplinary orientation of public art education in the turbulent utilitarianism.

\subsection{Looseness of course management.}

Effective curriculum management is the prerequisite and guarantee for improving educational effectiveness. However, the current curriculum management in college public art education is relatively loose. On one hand, with the absence of a clear orientation of the public art curriculum, many colleges and universities lack the overall curriculum design, and the public art curriculum has not been built as a general education curriculum, resulting in a more arbitrary and unstructured curriculum setting and management. The art curriculum does not set standards for college students' needs and it is based on the status of the teachers in the school and the number of students in the class. The phenomenon that schools set up classes based on the number of students is common. On the other hand, the selection and management of teaching materials is casual. For example, some colleges and universities directly use professional teaching materials such as photography, piano 
and literature of arts colleges. They do not seriously choose comprehensive textbooks that fit the common colleges. Their practicability is poor. Some college teachers develop textbooks independently. There are also problems, such as outdated content with low value and level, and the lack of features, which makes it difficult to achieve ideal teaching and management results.

\subsection{The lack of quality in teacher accomplishment.}

Good teacher accomplishment is the human support and intellectual guarantee for public art education. However, due to the complex composition of the professional teachers in the public art courses offered by some universities, it appears that any art -related teacher can teach public art. There exists no explicit requirement for the professional qualities of teachers. In reality, some professional counterparts with good professional qualities are reluctant to teach public art education courses. They think that public art courses are public general education courses and these courses do not require high professional qualities. At that time, few teachers were willing to devote themselves to the teaching of public art education courses when they can teach art majors. This leads to the prominent contradiction between the construction of full-time teams and the selection of public art education teachers.

\subsection{The closeness of the educational environment.}

The education process is dynamic, open, and continuously developing. Only when the teaching activities in and out of class, and in and outside the school are organically combined, can the school achieve wonderful results and enter a new realm of teaching. Public art education is no exception. However, at present, public art education in colleges and universities is more limited to the classroom and the university is accustomed to indoor listening, speaking, operation and performance. This ignores extracurricular art resources. The source of art is life. Only in actual life and activities, can public art education in colleges and universities obtain the growth of arts. In a closed education environment, students can only use the knowledge of books and the experience of teachers as learning materials. They ignore the students' ideological realities and social art practices, which suppresses the charm and vitality of art to a certain extent. This inevitably leads to passive deadlock.

\section{The Reform Ideas to Advance Public Art Education in Colleges}

\subsection{To clarify the orientation of public art education.}

Although there are various factors that impede the development of public art education in colleges, the orientation of disciplines is the most fundamental and critical factor. Unclear orientation will inevitably lead to misunderstanding and frustration of public art education. To this end, we must soberly realize that public art education is to enhance the aesthetic quality of the people. It is not advanced professional education. Therefore, the goal of public art education in colleges and universities is not to cultivate educated and excellent singers, composers and artists, but to allow college students to accept the beauty of the experience or the influence of art. This will serve the cultivation of the builders and successors with harmonious development of the morality, intelligence, physique and aesthetics. This is an indispensable part of the implementation of quality education. This determines that college public art education must be oriented to every student, and take all college students as the education object. It should take art popularization as the development direction and take the comprehensive improvement of college students' artistic quality as the basic task. To this end, the school authorities and staff should attach great importance to the construction of public art education in colleges and integrate the course to the entire curriculum system. Moreover, schools should give a right position of public art courses in the entire school education, such as film, drama and dance.

\subsection{To strengthen the management of public art courses.}

Teaching is the main approach to the implementation of curriculum, and disorderly management of the curriculum will inevitably lead to inefficiency or ineffectiveness of teaching. In the public 
arts education, colleges and universities should establish public art teaching departments and corresponding management institutions. They should be responsible for the art education work. Colleges should strengthen their job responsibilities. In particular, they must strictly implement the instructional spirit of the School Art Education Work Regulations. Colleges should optimize the curriculum system, and formulate corresponding art education curriculum plans, curriculum implementation rules and classroom teaching evaluation index system. Colleges should resolutely put an end to the randomness and subjectivity of public art education courses and constantly improve the public art education curriculum management mechanism. In addition, according to the actual need of college students, colleges should strictly select, use and evaluate teaching materials. On one hand, it is necessary to carry out adequate investigations and to develop national-level and exemplary public art education textbooks with universal guiding significance. On the other hand, according to the development of the region and the school and based on local conditions, colleges must strengthen the compilation of high-level textbooks to meet the artistic needs of college students from different regions, such as dance, opera, painting, and singing. In this way, the dynamic balance between national curriculum, local curriculum and school-based curriculum management can be achieved. Of course, qualified colleges and universities can set up a variety of compulsory courses and elective courses for arts, and enhance the flexibility of curriculum research and management.

\subsection{To improve the quality of public art teachers.}

A stable professional, full-time, and dedicated public art education teacher team is an important guarantee for the sound development of public art education in colleges and universities. In order to solve the contradiction in the allocation of teachers for public arts education in universities, the following measures are important. First of all, it is necessary to start with lessening the teaching pressure of art professional teachers. They can employ the artistic talented artisans and master craftsmen in the society as part-time teachers in public art education to take on certain tasks. They can also classify the professional teachers in the school according to their specialties and set targeted public art elective courses to maximize the decentralization of teaching tasks and pressures. Second, it is necessary to follow the rules and characteristics of art education. They should emphasize the inheritance and development of face-to-face skills, make appropriate cooperation agreements with social and cultural institutions, and arts groups, With the help of social resources, the public art education teachers' social practice ability can be strengthened and the content and forms of public art education in universities can be enriched. Finally, it is necessary to strengthen the appointment and reward system of art education teachers. The school should recognize and reward outstanding teachers, and punish or reject unqualified teachers. Only in this way can schools enhance the teachers' professional qualities and teaching standards, and build an outstanding and multi-talented teacher team with art and and science background.

\subsection{To open up environment of public art education.}

Breaking the closed environment and opening up it has become the development direction of college art education activities. On one hand, college art education should combine the reality of classroom teaching, create a good art atmosphere and organize rich and colorful extracurricular art activities to make extracurricular art activities an extension of classroom education. In addition to classroom teaching, regular or irregular events with different levels, different specifications and different themes should be held to allow students to experience spiritual joy and beauty in practical activities, such as painting photography, bodybuilding performances, poetry recitations, and calligraphy competitions. Therefore, they can understand the essence of art and this will promote a high degree of integration of art theory and art practice so that students can comprehend and apply knowledge. On the other hand, public art teaching in colleges and universities should step out of the narrow space of classrooms and schools, and move toward a broad social field. To this end, public art education in institutions of higher learning can integrate public art education into the production of society through the establishment of art practice bases, art parks, special lectures, volunteer activities and art performances. In the broad world, people can feel the charm of art, accept 
continuous supply of artistic culture and artistic nutrition, nurture and create more artistic works with aesthetic taste and aesthetic value, promote the spirit of the times, and promote the main theme of development. This will help build and create new public education platform for the development of colleges and universities.

\section{Conclusion}

In summary, colleges and universities should proceed from the actual situation in the reform of public art education, explore the countermeasures of public art education in the new era, meet the public art needs of contemporary college students, improve their level of art appreciation, and lay a good foundation for the progress of social art. In the process of education reform, colleges and universities should clarify the status of public art education and enhance their understanding of public art education; they must strengthen the management of public art education, set up scientific education courses to stimulate students' enthusiasm for art learning; schools should improve the quality of public art teachers, open up the public arts education environment and expand the public art perspective of teachers and students. Colleges should actively promote the spirit of the times, and make people feel the charm of art in artistic practice to achieve the goal of college public art education reform.

\section{References}

[1] Zhang Xuan. An Analysis of Perplexities and Reflections on College Public Art Education [J]. Contemporary Educational Science, 2013(07):57-59.

[2] Shao Ping. The Exploration of the Development Strategy of Contemporary Public Art Education in Colleges [J]. Heilongjiang Researches on Higher Education, 2015(03): 85-87.

[3] Zhao Sitong. A Discussion on Compilation of College Public Art Course Textbooks [J]. China Publishing Journal, 2017(14):44-46.

[4] Zhu Suhua. The Construction and Implementation of College Public Art Education Curriculum [J]. Jiangsu Higher Education, 2012(02):99-100.

[5] Ji Yumei. Reflections on College Public Art Education [J]. Jiangsu Higher Education, 2012 (06):145-146. 